\title{
Leakage of ammonium, urea, and dissolved organic nitrogen and carbon from eelgrass Zostera marina roots and rhizomes during sediment handling
}

\author{
Jens W. Hansen*, Bente Aa. Lomstein \\ Department of Microbial Ecology, Institute of Biological Sciences, University of Aarhus, Building 540, Ny Munkegade, \\ DK-8000 Aarhus C., Denmark
}

\begin{abstract}
The leakage of urea, ammonium, dissolved organic nitrogen, and dissolved organic carbon from Zostera marina root-rhizomes during different porewater extractions was examined. In addition, the concentrations of these compounds were measured in root-rhizomes to estimate the potential leakage from root-rhizomes during sediment handling. The concentrations of ammonium, urea, and dissolved organic nitrogen in root-rhizomes were 22 to 51 times higher than the respective average porewater concentrations within the upper $5 \mathrm{~cm}$ of the sediment. Up to $70 \%$ of the compounds in question leaked from root-rhizomes during sediment handling, with a resultant, up to 8 -fold, increase in the respective porewater concentrations. The porewater concentrations of ammonium, urea, and dissolved organic nitrogen and carbon were on average overestimated by a factor of 2 within the upper $5 \mathrm{~cm}$ of the sediment due to leakage from root-rhizomes. Thus, it is recommended that roots and rhizomes are removed from the sediment before porewater extraction by conventional methods
\end{abstract}

KEY WORDS: Zostera marina $\cdot$ Roots · Rhizomes · Sediment - Porewater · Leakage - Nitrogen · Carbon

\section{INTRODUCTION}

Seagrasses can have a large impact on pools and processes in the sediment, and there have been numerous studies on nitrogen and carbon pools and turnover rates in seagrass vegetated sediments (e.g. lizumi et al. 1982, Short 1983, Boon 1986, Blackburn et al. 1994). Seagrass roots and rhizomes have been demonstrated to excrete oxygen (Sand-Jensen et al. 1982, Smith et al. 1984) and dissolved organic compounds (Wetzel \& Penhale 1979, Moriarty et al. 1986), which may affect pools and processes in the sediment (Caffrey \& Kemp 1990, Pollard \& Moriarty 1991. O'Donohue et al. 1991, Welsh et al. 1997, Blaabjerg et al. 1998). The potential leakage of dissolved compounds from root-rhizomes during sediment handling may cause experimental problems. In most studies

\footnotetext{
- Present address: National Environmental Research Institute, Vejlsøvej 25, DK-8600 Silkeborg, Denmark.

E-mail: jwh@dmu.dk
}

root-rhizomes have not been removed before sediment handling, but the potential methodical problem was acknowledged by Caffrey \& Kemp (1990). They removed root-rhizomes from the sediment before nitrogen pools and transformation rates were measured to avoid uptake or leakage of ammonium and dissolved organic carbon from root-rhizomes.

Howes et al. (1985) and Hines et al. (1994) demonstrated that dissolved compounds leaked from roots of Spartina alterniflora, when porewater was obtained by centrifugation or sediment squeezing. Methods like sipper and dialysis have been developed to obtain porewater with minimal sediment disturbance (Hesslein 1976, Zimmermann et al. 1978). However, sippers have the disadvantage that the depth interval of porewater collection is not well defined, and dialysis requires a long equilibration period, where the porewater may be oxidised (Howes et al. 1985, Carignan et al. 1994). To our knowledge, there have not been any studies on solute leakage from seagrass root-rhizomes during sediment handling and the resultant effect on porewater concentrations. 
The aim of the present study was to quantify the leakage of urea, $\mathrm{NH}_{4}{ }^{+}$, dissolved organic nitrogen (DON), and dissolved organic carbon (DOC) from eelgrass Zostera marina root-rhizomes during conventional porewater extraction methods such as centrifugation with or without preceding $\mathrm{KCl}$ extraction.

\section{MATERIALS AND METHODS}

Sampling and storage. Sediment cores with Zostera marina were sampled from an eelgrass bed in the cove Kalø Vig, Jutland, Denmark in May and October 1994. The water depth was $1 \mathrm{~m}$, the water temperature was $14^{\circ} \mathrm{C}$, and the salinity was $22 \%$ in both May and October. In October, the shoot density in the eelgrass bed was $\sim 1100$ shoots $\mathrm{m}^{-2}$. The shoot density was not measured in May. The cores were submerged in aerated water from the sampling locality and transported back to the laboratory within $2 \mathrm{~h}$ after sampling. In the laboratory, the cores were kept at the in situ temperature and in a $14: 10 \mathrm{~h}$ light:dark cycle to recover from the sampling disturbances. The plants were stored for about 2 wk before the sediment was processed. During that time the plants were growing and looked healthy.

Processing. In May and October 1 core $(4.6 \mathrm{~cm}$ i.d.) and 2 cores (9.4 cm i.d.), respectively, were sectioned into $1 \mathrm{~cm}$ depth intervals within the main root zone $(0$ to $5 \mathrm{~cm})$. In each sediment section the root-rhizomes were removed by tweezers from one half of the sediment. The other half of the sediment was treated in a similar manner, but root-rhizomes were not removed. The sediment with root-rhizomes (sedt) and the sediment without root-rhizomes (sed-) were homogenised. In May, $4 \mathrm{~cm}^{3}$ of sed + and sed-were extracted in $4 \mathrm{ml}$ of nitrogen free artificial seawater (ASW) for $30 \mathrm{~min}$ at room temperature. The slurry was centrifuged at $1300 \times g$ for $6 \mathrm{~min}$, and the supernatant was $0.2 \mu \mathrm{m}$ (Sartorius) filtered and frozen for later analysis. In October, $6 \mathrm{~cm}^{3}$ of sed+and sed-were extracted in $6 \mathrm{ml}$ $1 \mathrm{M} \mathrm{KCl}$ for $30 \mathrm{~min}$ at $0^{\circ} \mathrm{C}$. The sediment- $\mathrm{KCl}$ mixture was centrifuged at $1300 \times g$ for $6 \mathrm{~min}$, and the supernatant was $0.2 \mu \mathrm{m}$ (Sartorius) filtered and frozen for later analysis. In addition, $20 \mathrm{~cm}^{3}$ of sed+ and sedwere centrifuged at $1300 \times g$ for 6 min, and the supernatant was $0.2 \mu \mathrm{m}$ (Sartorius) filtered and frozen for later analysis. Finally, porewater was obtained from $20 \mathrm{~cm}^{3}$ of sedt and sed-by pneumatic squeezing through a $0.45 \mu \mathrm{m}$ filter (Millipore) at 4 atm and frozen for later analysis. The sediment extractions with ASW or $\mathrm{KCl}$ followed by centrifugation, the direct centrifugation and the pneumatic squeezing of sediment will in the following be referred to as ASW-CF, KCI-CF, CF and PS extractions, respectively. In October, the roots and rhizomes removed from each depth interval were separated, rinsed with ASW, crushed in a mortar and mixed with $50 \mathrm{ml}$ of ASW. The mixture was filtered through a Whatman GF/F filter, followed by filtration through a $0.2 \mu \mathrm{m}$ (Sartorius) filter and frozen for later analysis. In May, plants from a core were carefully rinsed free of sediment and the roots were cut. The roots were processed as described for the root-rhizomes from October. All filters used in the experiments were rinsed with $5 \mathrm{ml}$ ASW before filtration. ASW $(5 \mathrm{ml})$ or $\mathrm{KCl}(5 \mathrm{ml})$ filtered through prerinsed filters were used as blanks. The sediment density was determined in each depth interval from the weight of triplicate $2 \mathrm{~cm}^{3}$ fresh sediment. The water content in sediment and root-rhizomes was determined as the weight loss of fresh sediment and root-rhizomes dried at $105^{\circ} \mathrm{C}$ to a constant weight.

Analysis. Urea, $\mathrm{NH}_{4}{ }^{+}$, and $\mathrm{NO}_{3}{ }^{-}$were analysed on a Technicon autoanalyser after the methods described in Price \& Harrison (1987), Bower \& Holm-Hansen (1980), and Technicon AutoAnalyser Industrial Methods, respectively. Total dissolved nitrogen (TDN) and DOC were analysed on an Antek 7000 system, which in principle was as described in Hansell et al. (1993) with the modifications described in Lomstein et al. (1998). The concentration of DON was calculated as the concentration of TDN minus the concentration of $\mathrm{NH}_{4}{ }^{+}+$ $\mathrm{NO}_{3}{ }^{-}$.

Calculations. The actual leakage of urea, $\mathrm{NH}_{4}{ }^{+}$, DON, and DOC from root-rhizomes was estimated from the difference in concentrations between sed+ and sed-:

Actual leakage $\left(\mathrm{nmol} \mathrm{cm}{ }^{-3}\right)=\frac{([\text { sed }+]-[\text { sed }-]) \times V_{\mathrm{pw}}}{V_{\text {sed }}}$ where $[$ sed +$]$ and [sed $-\mid$ were the concentrations (nM) of the solutes extracted from sediment with and without root-rhizomes, respectively, $V_{\mathrm{pw}}$ was the volume (l) of porewater, and $V_{\text {sed }}$ was the sediment volume $\left(\mathrm{cm}^{3}\right)$ from which porewater was obtained. The potential leakage of urea, $\mathrm{NH}_{4}{ }^{+}, \mathrm{DON}$, and DOC from root-rhizomes was calculated from the following formulation:

$$
\text { Potential leakage }\left(\text { nmol cm}{ }^{-3}\right)=\frac{C_{\text {rt-rh }} \times V_{\text {rt-rh }}}{V_{\text {sed }}}
$$

where $C_{\mathrm{rt}-\mathrm{rh}}$ was the concentration (nM) of the solute in root-rhizomes, $V_{\mathrm{rt}-\mathrm{rh}}$ was the volume (l) of root-rhizomes, and $V_{\text {sed }}$ was the sediment volume $\left(\mathrm{cm}^{3}\right)$ from which root-rhizomes were removed. Accordingly, the ratio between the measured and the potential leakage was the fraction of the dissolved compounds in rootrhizomes which leaked during extraction.

Statistical analysis. Data in tables are, when possible, presented as a mean value \pm the standard error (SE) of the mean. A 2-tailed Student's t-test was used for comparison of data. 


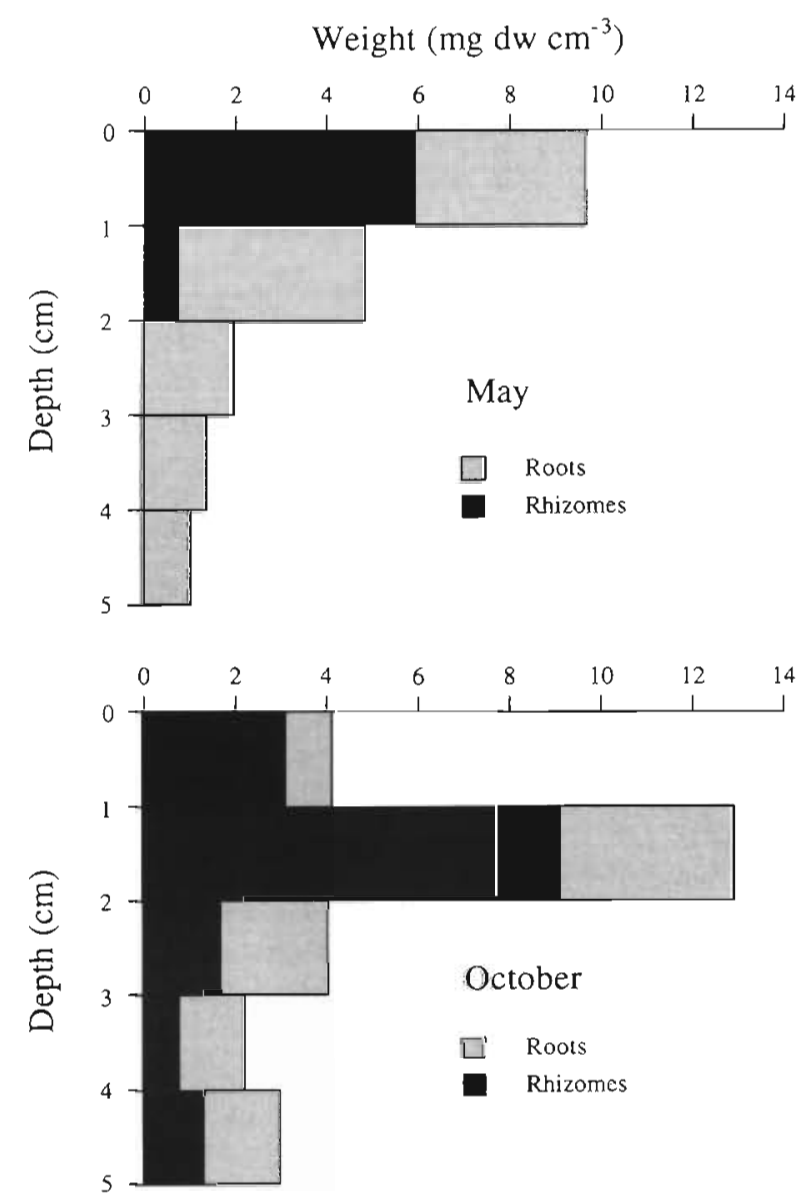

Fig. 1. Vertical profiles of root and rhizome dry weight (dw) in May (upper panel) and October (lower panel)

\section{RESULTS AND DISCUSSION}

The biomass of Zostera marina root-rhizomes within the upper $5 \mathrm{~cm}$ of the sediment was 189 and $263 \mathrm{~g} \mathrm{dw}$ $\mathrm{m}^{-2}$ in May and October, respectively, and the volume of root-rhizomes accounted for $\sim 2 \%$ of the sediment volume. Most of the root-rhizomes were within the upper 2 to $3 \mathrm{~cm}$ of the sediment with a maximum in the 0 to $1 \mathrm{~cm}$ depth strata in May and in the 1 to $2 \mathrm{~cm}$ depth

Table 1. Average concentrations of urea-N, $\mathrm{NH}_{4}{ }^{+}, \mathrm{DON}$, and DOC (mM) in Zostera marina root-rhizomes from the 0 to $5 \mathrm{~cm}$ depth interval. Values in pararentheses are SE of mean $(n=5$, as measurements were made in each of the 5 depth strata). In May the 0 to $5 \mathrm{~cm}$ depth interval was not sectioned and SE could not be calculated. nm: not measured

\begin{tabular}{|lcccc|}
\hline & Urea-N & $\mathrm{NH}_{4}{ }^{+}$ & DON & DOC \\
\hline Roots, May & 0.5 & 1.8 & $\mathrm{~nm}$ & $\mathrm{~nm}$ \\
Roots, October & $0.2(0.1)$ & $1.4(0.3)$ & $17(3)$ & $734(138)$ \\
Rhizomes, October & $0.3(0.1)$ & $0.6(0.2)$ & $12(2)$ & $992(306)$ \\
\hline
\end{tabular}

strata in October (Fig. 1). The difference in the profile of root-rhizomes between May and October was presumably due to the fact that the cores sampled in May were from a younger part of the eelgrass bed than in October. In October, rhizomes were present in all depths.

The average concentrations of urea, $\mathrm{NH}_{4}{ }^{+}, \mathrm{DON}$, and DOC in roots and rhizomes of Zostera marina were $0.2-0.5,0.6-1.8,12-17$, and $734-992 \mathrm{mM}$, respectively (Table 1). The concentration of $\mathrm{NH}_{4}{ }^{+}$was significantly higher in roots than in rhizomes $(p=0.03)$. The concentrations of urea and $\mathrm{NH}_{4}{ }^{+}$in roots were higher in May than in October. This may have been due to consumption of stored nitrogen during the summer months where eelgrass growth reaches its maximum (Pedersen \& Borum 1993, Burke et al. 1996). However, the difference in the root concentrations of urea and $\mathrm{NH}_{4}{ }^{+}$between May and October could also have been due to the fact that cores were sampled in different parts of the eelgrass bed in May and October, respectively. It is likely that the high concentration of DOC in root-rhizomes was due to stored carbohydrates. Similarly, Kraemer \& Alberte (1995) and Burke et al. (1996) found high concentrations of sugars and starch in rootrhizomes of $Z$. marina.

The porewater concentrations of urea, $\mathrm{NH}_{4}{ }^{+}, \mathrm{DON}$, and DOC obtained by the ASW-CF and the CF extractions of sed-in May and October are shown in Fig. 2. In October, the concentrations of urea, $\mathrm{NH}_{4}{ }^{+}, \mathrm{DON}$, and DOC in root-rhizomes were 31,22, 51 and 276 times higher, respectively, than the respective average porewater concentrations in the upper $5 \mathrm{~cm}$ of the sediment. It was not possible to draw any conclusions on potential $\mathrm{NO}_{3}^{-}$leakage from root-rhizomes, as there were indications of $\mathrm{NH}_{4}{ }^{+}$oxidation to $\mathrm{NO}_{3}{ }^{-}$during sediment handling. However, the effect of this oxidation on the $\mathrm{NH}_{4}{ }^{+}$pool was neglectable as less than $5 \%$ of the porewater $\mathrm{NH}_{4}{ }^{+}$was oxidised during the sediment handling (data not shown).

Approximately $40,50,60$, and $10 \%$ of the contents of urea, $\mathrm{NH}_{4}{ }^{+}, \mathrm{DON}$, and DOC, respectively, in root-rhizomes leaked during sediment handling (Table 2). The relatively limited leakage of DOC may have been due to an overestimation of the DOC pool in root-rhizomes. The DOC content was measured on crushed root-rhizomes, which may have caused a dissolution of stored carbohydrates. The leakage of urea, $\mathrm{NH}_{4}{ }^{+}, \mathrm{DON}$ and $\mathrm{DOC}$ from root-rhizomes to the sediment was within the same range in the ASW-CF, PS, CF and $\mathrm{KCl}-\mathrm{CF}$ extractions. The relatively large standard errors on the average leakages were primarily due to the vertical variation in the biomass of root-rhizomes

The ratios between sed+ and sed-porewater concentrations of urea, $\mathrm{NH}_{4}{ }^{+}, \mathrm{DON}$, and DOC within the upper $5 \mathrm{~cm}$ of the sediment in May (ASW-CF extrac- 

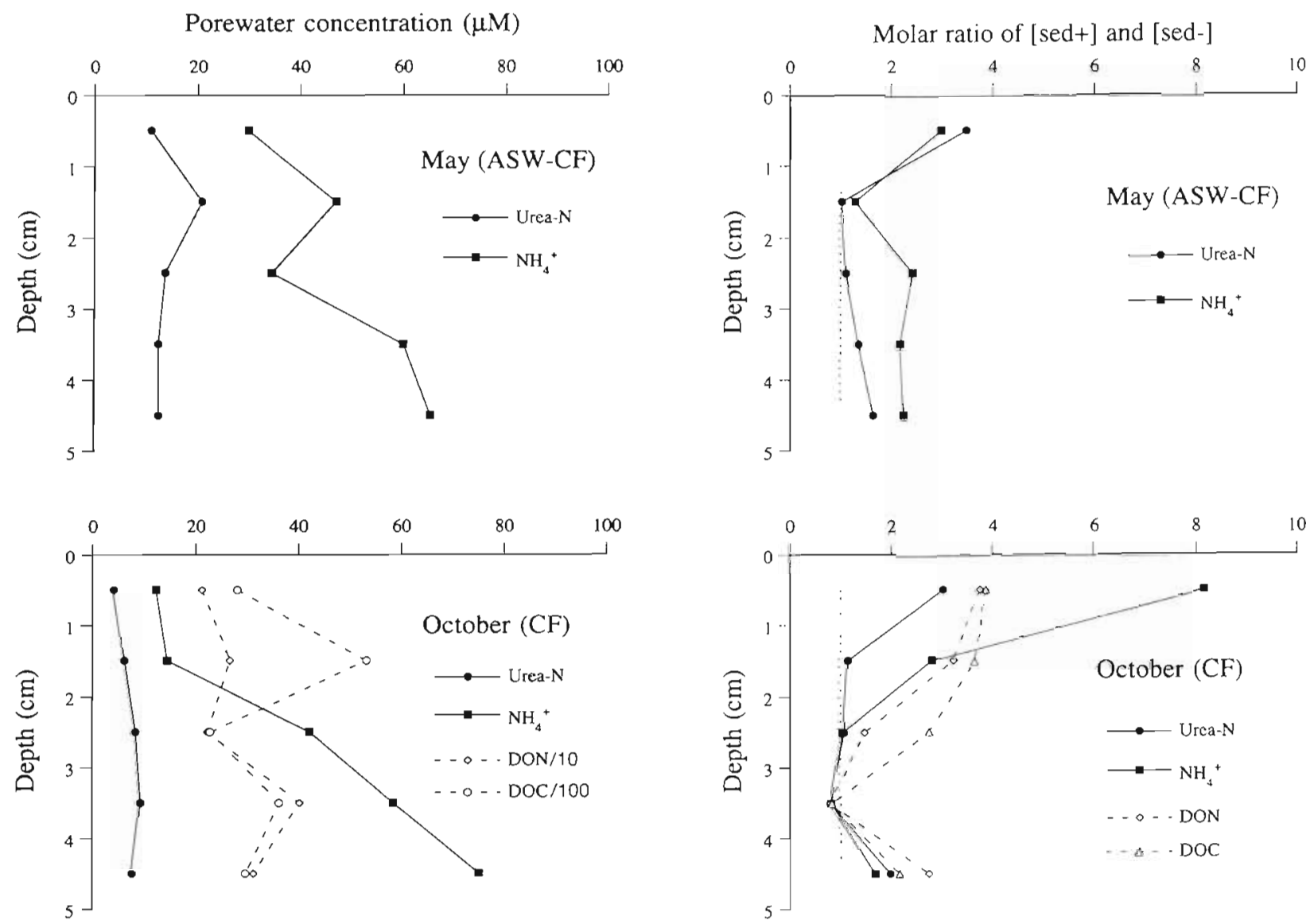

Fig. 2. Vertical profiles of porewater concentrations of urea-N and $\mathrm{NH}_{4}{ }^{+}$in May (upper panel) and urea-N, $\mathrm{NH}_{4}{ }^{+}$, DOC and DON in October (lower panel). Root-rhizomes were removed before sediment was extracted with ASW followed by centrifugation (ASW-CF) or centrifuged (CF). The concentrations of DON and DOC are divided by 10 and 100 , respectively

Fig. 3. Ratio between concentrations in sediment with (sed+) and without (sed-) root-rhizomes in May and October, respectively. The sediment was extracted with ASW followed by centrifugation (ASW-CF) or centrifuged (CF). The dashed lines indicate a sed $+/$ sed - ratio of 1

Table 2. Actual and potential leakage of urea- $\mathrm{N}_{1} \mathrm{NH}_{4}{ }^{+}, \mathrm{DON}$, and DOC (nmol cm$~^{-3}$ of sediment) from Zostera marina root-rhizomes in the main root zone. ASW-CF: ASW extraction of the sediment followed by centrifugation; PS: porewater obtained by pneumatic squeezing; CF: porewater obtained by centrifugation; $\mathrm{KCl}-\mathrm{CF}$ : $\mathrm{KCl}$ extraction of the sediment followed by centrifugation. The actual leakage from root-rhizomes in May (ASW-CF) could not be related to a potential leakage from root-rhizomes as concentrations only were measured in roots. Values in pararentheses are $\mathrm{SE}$ of mean $(\mathrm{n}=5$, as measurements were made in each of the 5 depth strata). nm: not measured

\begin{tabular}{|lcccc|}
\hline & Urea-N & $\mathrm{NH}_{4}{ }^{*}$ & DON & DOC \\
\hline Actual, $\mathrm{ASW}-\mathrm{CF}_{0-5 \mathrm{~cm}}$ & $3.4(1.9)$ & $23.8(5.7)$ & $\mathrm{nm}$ & $\mathrm{nm}$ \\
${\text { Actual, } \mathrm{PS}_{0-1} \mathrm{~cm}}_{\text {Potential }}$ & $\mathrm{nm}$ & 4.5 & 273 & 405 \\
Actual, $\mathrm{CF}$ & 2.7 & 10.2 & 374 & 19416 \\
Actual, $\mathrm{KCl}-\mathrm{Cm}$ & $1.1(0.7)$ & $11.0(6.4)$ & $120(49)$ & $2004(867)$ \\
Potential & $2.3(1.0)$ & $7.1(9.1)$ & $111(73)$ & $2331(962)$ \\
Ratio (actual/potential) & $0.3-0.5$ & $0.4-0.7$ & $0.5-0.7$ & $0.0-0.1$ \\
& & & & \\
\hline
\end{tabular}

tion) and October (CF extraction) are shown in Fig. 3. The overestimation of porewater concentrations, due to leakage from root-rhizomes, was greatest within the upper $2 \mathrm{~cm}$ of the sediment, which contained $-70 \%$ of the root-rhizome biomass within the 0 to $5 \mathrm{~cm}$ depth strata. The concentrations of urea, $\mathrm{NH}_{4}{ }^{+}, \mathrm{DON}$, and $\mathrm{DOC}$ in porewater extracted from the upper $5 \mathrm{~cm}$ of sed+ were on average 1.2 to 2.9-fold higher than the respective concentrations in sed-(Table 3). The overestimation of porewater concentrations of $\mathrm{NH}_{4}{ }^{+}$was lower, although not significantly $(p>0.05)$, in the $\mathrm{KCl}-\mathrm{CF}$ than the other extractions. This was due to $\mathrm{K}^{+}$ exchange of $\mathrm{NH}_{4}{ }^{+}$from the sediment, which decreased the relative effect of $\mathrm{NH}_{4}{ }^{+}$leakage from root-rhizomes (data not shown). 
Table 3. Ratios between concentrations of urea- $\mathrm{N}, \mathrm{NH}_{4}{ }^{+}$, DON, and DOC in sed+ and sed-. ASW-CF: ASW extraction of the sediment followed by centrifugation; PS: porewater obtained by pneumatic squeezing; CF: porewater obtained by centrifugation; $\mathrm{KCl}-\mathrm{CF}: \mathrm{KCl}$ extraction of the sediment followed by centrifugation. Values in parentheses are SE of mean ( $\mathrm{n}=5$, as measurements were made in each of the 5 depth strata). nm: not measured

\begin{tabular}{|lcccc|}
\hline & Urea-N & $\mathrm{NH}_{4}{ }^{+}$ & DON & DOC \\
\hline $\mathrm{ASW} \mathrm{CF}_{0-5 \mathrm{~cm}}$ & $1.7(0.5)$ & $2.2(0.3)$ & $\mathrm{nm}$ & $\mathrm{nm}$ \\
$\mathrm{PS}_{0-1 \mathrm{~cm}}$ & $\mathrm{~nm}$ & 1.7 & 1.6 & 1.2 \\
$\mathrm{CF}_{0-5 \mathrm{~cm}}$ & $1.6(0.4)$ & $2.9(1.4)$ & $2.4(0.5)$ & $2.6(0.6)$ \\
$\mathrm{KCl} \mathrm{CF}_{0-5 \mathrm{~cm}}$ & $1.7(0.5)$ & $1.3(0.3)$ & $1.5(0.4)$ & $1.9(0.3)$ \\
\hline
\end{tabular}

Leakage of dissolved inorganic and organic compounds from root-rhizomes during sediment handling may be a general problem in sediments vegetated with macrophytes. As a consequence, an overestimation of porewater concentrations of these compounds can be expected if root-rhizomes are not removed from the sediment before porewater extraction by conventional methods. Further, leakage of dissolved compounds from root-rhizomes during sediment incubations can potentially affect rate measurements.

Acknowledgements. We thank Jørgen Berntsen for the analysis of DON and DOC. Financial support was obtained from the Centre for Strategic Research in Marine Areas, Grant no. 4.15 .

\section{LITERATURE CITED}

Blaabjerg V, Mouritsen KN, Finster K (1998) Diel cycles of sulphate reduction rates in sediments of a Zostera marina bed (Denmark). Aquat Microb Ecol 15:97-102

Blackburn TH, Nedwell DB, Wiebe WJ (1994) Active mineral cycling in a Jamaican seagrass sediment. Mar Ecol Prog Ser 110:233-239

Boon PI (1986) Nitrogen pools in seagrass beds of Cymodocea serrulata and Zostera capricorni of Moreton Bay, Australia. Aquat Bot 25:1-19

Bower CE, Holm-Hansen T (1980) A salicylate-hypochlorite method for determining ammonia in seawater. Can $J$ Fish Aquat Sci 37:794-798

Burke MK, Dennison WC, Moore KA (1996) Non-structural carbohydrate reserves of eelgrass Zostera marina. Mar Ecol Prog Ser 137:195-201

Caffrey JM, Kemp WM (1990) Nitrogen cycling in sediments with estuarine populations of Potamogeton perfoliatus and Zostera marina. Mar Ecol Prog Ser 66:147-160

Carignan R, St-Pierre S, Gächter R (1994) Use of diffusion samplers in oligotrophic lake sediments: effects of free oxygen in sampler material. Limnol Oceanogr 39:468-474

Hansell DA, Williams PM, Ward BB (1993) Measurements of

Editorial responsibility: Gary King

Walpole, Maine, USA
DOC and DON in the Southern California Bight using oxidation by high temperature combustion. Deep-Sea Res 40 : 219-234

Hesslein RH (1976) An in situ sampler for close interval pore water studies. Limnol Oceanogr 21:913-914

Hines ME, Banta GT, Giblin AE, Hobbie JE (1994) Acetate concentrations and oxidation in salt-marsh sediment. Limnol Oceanogr 39:140-148

Howes BL, Dacey JWH, Wakeham SG (1985) Effects of sampling technique on measurement of porewater constituents in salt marsh sediments. Limnol Oceanogr 30 : $221-227$

lizumi H, Hattori A, McRoy CP (1982) Ammonium regeneration and assimilation in eelgrass (Zostera marina) beds. Mar Biol 66:59-65

Kraemer GP, Alberte RS (1995) Impact of daily photosynthetic period on protein synthesis and carbohydrate stores in Zostera marina L. (eelgrass) roots: implications for survival in light-limited environments. J Exp Mar Biol Ecol 185: 191-202

Lomstein B Aa, Jensen AU, Hansen JW, Andreasen J, Hansen LS, Berntsen J, Kunzendorf H (1998) Budgets of sediment nitrogen and carbon cycling in the shallow water of Knebel Vig, Denmark. Aquat Microb Ecol 14:69-80

Moriarty DJW, Iverson RL, Pollard PC (1986) Exudation of organic carbon by the seagrass Halodule wrightii Aschers. and its effect on bacterial growth in the sediment. J Exp Mar Biol Ecol 96:115-126

O'Donohue MJ, Moriarty DJW, MacRae IC (1991) Nitrogen fixation in sediments and the rhizosphere of the seagrass Zostera capricorni. Microb Ecol 22:53-64

Pedersen MF, Borum J (1993) An annual nitrogen budget for a seagrass Zostera marina population. Mar Ecol Prog Ser 101:169-177

Pollard PC, Moriarty DJW (1991) Organic carbon decomposition, primary and bacterial productivity, and sulfate reduction, in tropical seagrass beds of the Gulf of Carpentaria, Australia. Mar Ecol Prog Ser 69:149-159

Price NM, Harrison PJ (1987) Comparison of methods for the analysis of dissolved urea in seawater. Mar Biol 94: $307-317$

Short FT (1983) The response of interstitial ammonium in eelgrass (Zostera marina L.) beds to environmental perturbations. J Exp Mar Biol Ecol 68:195-208

Sand-Jensen K, Prahl C, Stokholm H (1982) Oxygen release from roots of submerged aquatic macrophytes. Oikos 38 : 349-354

Smith RD, Dennison WC, Alberte RS (1984) Role of seagrass photosynthesis in root aerobic processes. Plant Physiol 74: 1055-1058

Welsh DT, Bourguès S, de Wit R, Auby I (1997) Effect of plant photosynthesis, carbon sources and ammonium availability on nitrogen fixation rates in the rhizosphere of Zostera noltii. Aquat Microb Ecol 12:285-290

Wetzel RG, Penhale PH (1979) Transport of carbon and excretion of dissolved organic carbon by leaves and root/rhizomes in seagrasses and their epiphytes. Aquat Bot 6: $149-158$

Zimmermann CF, Price MT, Montgomery JR (1978) A comparison of ceramic and Teflon in situ samplers for nutrient pore water determination. Estuar Coast Mar Sci 7 : 93-97

Submitted: February 24, 1998; Accepted: July 16, 1998

Proofs received from author(s): January 12, 1999 